\title{
Does the Size Matter for Dynamics Capabilities? A Study on Absorptive Capacity
}

\author{
Marlon Fernandes Rodrigues Alves ${ }^{{ }^{*}}$, Jessâmine Thaise Sartorello Salvini ${ }^{1}$, Ana Claudia Bansi ${ }^{1}$, \\ Elio Galli Neto ${ }^{1}$, Simone Vasconcelos Ribeiro Galina ${ }^{1}$
}

\begin{abstract}
The objective of this study is to understand how organizational size influences dynamic capabilities in Brazil. To arrive at this understanding, structural equation modeling analysis was performed using the Brazilian Innovation Survey (PINTEC) database to test for differences between SMEs and large companies in respect to the relationship between absorptive capacity (AC) dimensions and innovation performance. The results show that in large companies, Potential AC and Realized AC impact innovation performance, whereas in small and medium-sized enterprises (SMEs), only Realized AC has an influence. In addition, SMEs are, in fact, better at converting Realized AC into innovation performance than large companies, probably due to their flexibility and agility. These findings reveal that organizational sizes influence the impact of dynamic capabilities on performance.
\end{abstract}

Keywords: dynamic capabilities; absorptive capacity; innovation performance; SME; ICT.

Submitted: August 30th 2016/ Approved: September 12th 2016

\section{Introduction}

The objective of this paper is to understand how organizational size influences dynamic capabilities (DC). This topic is particularly relevant because while size is one of the most analyzed organizational characteristics in the innovation field, its relation to DC theory remains an open question.

DC is recognized as the ability of an organization to create, extend and modify intentionally its resource base (Constance E. Helfat et al., 2007). Resources understood here refer to tangible resources, intangible resources, human resources or a combination of them. The capabilities of these resources are required to achieve long-term competitive advantages over competitors. Additionally, in terms of the assumptions of DC theory, capabilities are path dependent and rely on organizational routines that are strongly standardized and repeatable by the company (Teece, Pisano, \& Shuen, 1997; Zollo \& Winter, 2002)

However, there are controversies. According to Eisenhardt \& Martin (2000) and Schilke (2014), DC is not necessarily part of standardized routines, particularly in high-velocity markets. The authors state that the development of DC for high-velocity markets depends on new knowledge created for specific situations. In this context, routines become interactive, adaptive and nonlinear. Therefore, the processes yield unstable and unpredictable results.

This duality leaves open the following question: does understanding DC as a result of past trajectories and well-defined routines, which are generally more evident in large companies, present a difficulty for small and medium-sized enterprises (SMEs) in developing DC?

The objective of this paper is to shed light on this issue by analyzing the $\mathrm{AC}$ of companies in Brazil. Absorptive capacity (AC) is understood as DC (Zahra \& George, 2002) responsible for enabling a company to value, assimilate, and apply new knowledge to develop new products (Cohen \& Levinthal, 1990). Since, in most cases, the relevant external knowledge presents itself in a complex and poorly coded form, this capability is important because it plays a leading role in the company's ability to understand the value of that external knowledge and to recombine it with its existing knowledge base.

Cantú, Criado, \& Criado (2009) note that large companies typically rely on systematic mechanisms to manage knowledge-based resources, while SMEs still need to understand their knowledge and how to explore and share it to improve competitiveness. Moreover, large companies usually have more management structures, more sophisticated routines, and more resources to invest in $R \& D$, while SMEs rely heavily on the technical and industrial experience of the company owner to develop AC, which in turn affects the innovation performance of SMEs (Wang, Wang, \& Horng, 2010). Because SMEs represent usually more than $90 \%$ of a nation's business, improving their innovation performance may significantly increase national income (Wang et al., 2010).

Therefore, this paper seeks to contribute to the literature, since most of the publications on DC are conceptual. Moreover, the more limited number of empirical studies happens mostly in companies in developed countries. Hence, emerge the contribution of studying DC empirically, and doing so in an emerging country. To achieve the goal, this paper is divided as follows: the theoretical review will cover first, the conceptual basis of DC and AC, and secondly, the consequences of organizational size to the development of capabilities. Then, it's presented the method and results. And finally, the discussion and closing remarks are presented.

(1) School of Economics, Business Administration and Accounting at Ribeirao Preto, University of Sao Paulo, Brazil

*Corresponding author: mfralves@fearp.usp.br 


\section{Theoretical background}

\subsection{Dynamic capabilities and absorptive capacity}

The definition of DC must go through the definition of capability, as Constance E. Helfat \& Winter (2011) defined as a reliable and minimally satisfactory manner to perform an activity repeatedly (for example, a factory that builds computers that work). In this sense, all firms have capabilities, in particular the so-called operational or zeroorder capabilities, which allow them to manufacture or sell goods or services (Arend, 2014).

Although research on DC has not reached maturity, the term DC can be seen as "the ultimate organizational capability that conducts performance in the long run" (Wang \& Ahmed, 2007). Teece (2007) defines DC as a set of capabilities to sense and shape opportunities and threats, seize opportunities and sustain competitive advantage through assets reconfiguration when necessary. Following this view, it is safe to say that all firms have capabilities, but not all firms have DC, as the latter need to be developed with a view toward long-term competitive advantage (Arend, 2014; Teece, 2016).

$\mathrm{AC}$ is a specific kind of DC. In general, AC means to evaluate and use external knowledge, that is, to learn with potential partners, integrate external information and turn them into an ingrained capability within the organization (Teece, 2007; Wang \& Ahmed, 2007), allowing the company to respond quickly to strategic changes (Sun \& Anderson, 2010). Given the implications of the learning process for competitiveness, Zahra \& George (2002) conceptualize AC as DC itself. For them, AC is defined as "a set of routines and organizational processes through which firms acquire, assimilate, transform and exploit knowledge" (Zahra \& George, 2002, p. 186).

$\mathrm{AC}$ can be analyzed in two distinct and complementary dimensions: the potential capacity (Potential AC - knowledge acquisition and assimilation) and the realized capacity (Realized AC - knowledge transformation and exploration) (Zahra \& George, 2002). This study adopts this framework (Figure 1), where Realized AC mediates the relationship between Potential AC and Innovation Performance.

Figure 1. Absorptive capacity framework.

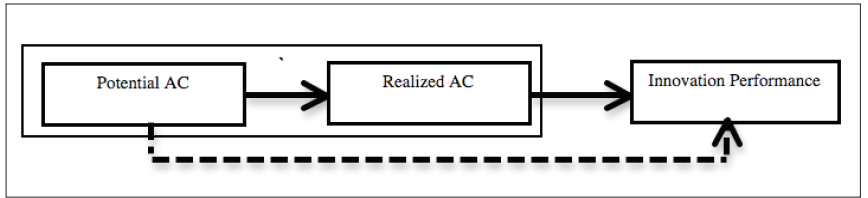

Note. Adapted from Zahra and George (2002).

The dotted line represents an indirect effect (mediation) expected to be not significant.

By acquiring and assimilating external knowledge, Potential AC allows the company to receive external knowledge (Zahra \& George, 2002). It is important to emphasize that the higher the level of Potential AC is, the greater is the organization's ability to understand and interpret, increasing the likelihood of the company to anticipate changes, modify strategies and achieve appropriate qualifications (Ben-Menahem, Kwee, Volberda, \& Van Den Bosch, 2013). The acquisition process within Potential AC represents the intuition and interpretation required of individuals and groups on the new external knowledge (Sun \& Anderson, 2010). On the other hand, assimilation is influenced by team members' experience and is strengthened by the prosperous environment for innovation; it is implemented at the group level and not just at the individual level (Sun \& Anderson, 2010).

Realized AC transforms knowledge that has been assimilated as a result of developing routines that facilitate the integration of newly acquired knowledge with existing knowledge and is formed by the dimensions of transformation and exploitation (Zahra \& George, 2002). Leadership and expertise of individuals to stimulate the shared understanding of newly acquired and assimilated knowledge influence the transformation process (Sun \& Anderson, 2010). The exploration process happens on the organizational level and is related to the rewarding of activities, recognition and effective timely implementation of the company's resources, creating an organizational memory (Sun \& Anderson, 2010).

\subsection{Dynamic capabilities and organizational size}

DC were identified primarily in studies concerning large and multinational firms, within highly dynamic sectors, such as ICT, but recent work has shown that such capabilities also exist in young firms and SMEs in different sectors (Alves, Zen, \& Padula, 2011; Arend, 2014). Business administration and management studies in general have traditionally focused on large organizations as a background for research, arguing that in these firms, problems are more clearly identified or that there is little differentiation between managing large firms and SMEs. Following this concept, it would be enough to attack the deficits that a given SME has when compared to a large firm (Frank \& Roessl, 2015).

Recent work has emphasized the need to expand research on the identification and development of DC in SMEs because of the lack of studies on the issue. Economic theory encounters difficulties with explaining different performances among firms in cases where this relates to the capacity of orchestrating resources and perceiving opportunities ahead of competitors (Arend, 2014; C. E. Helfat \& Martin, 2015; Teece, 2016). In addition, SMEs are the world's most common form of enterprise structure, representing one of the most urgent research topics in the social sciences and in economics (Frank \& Roessl, 2015).

Most SMEs find stability and operate successfully without ever becoming a large firm, while only a few actually grow into larger enterprises. Nevertheless, this smaller group has been the focus of research in DC, making it almost impossible to draw generalizations due to firm heterogeneity (Curran \& Blackburn, 2001). Nevertheless, a small business is not a "small big business". Therefore, such a relation cannot be established without some loss for studies on SMEs. This is because the differentiations go beyond quantitative data regarding size and concern mostly qualitative peculiarities (Curran \& Blackburn, 2001). 
SMEs demand a specific set of DC to survive and search for abilities and competencies that allow the firm to pursue the necessary adjustments for growth and development (Zahra et al., 2006). According to Frank \& Roessl (2015), SME management studies traditionally relate to issues that can be characterized in the following way:

- They possess less favorable prerequisites to achieve economies of scale and economies of scope;

- Changes in the company size strongly influence the internal resource organization;

- Smaller sizes and bigger transparency combined with less formality promotes advantages with organizational costs;

- Growth related decision or personal hiring involve comparatively riskier decisions, which have more potential impact on the whole business;

- Exclusive individual knowledge creates a high dependency on a small number of people;

- Managerial decisions are critical and usually without the support of specialists or multiple decision makers;

- A high level of uncertainty increases business related risks, demanding higher efforts in managing stakeholder relations;

- An individual SME is not economically relevant, demanding a need to acknowledge the relevance in trade associations and networks;

- There is a high dependence on external forces, as they are more susceptible to regulations and economic policies.

While several authors have recognized the dominant role played by the decision maker in the development of DC (Helfat \& Martin, 2015; Rindova \& Kotha, 2001; Teece, 2016), the decision maker/manager/ entrepreneur in SMEs usually is the same person. This entrepreneurial manager is more related to the day-to-day operations and responsible for the administrative, strategic and operational decisions in SMEs (Adner \& Helfat, 2003; Arend, 2014).

The usual DC view on management studies already has an entrepreneurial approach that emphasizes the importance of internally and externally related processes, recognizing the importance of critical resources and strategy (Teece, 2016). Entrepreneurial firms discover, create, define and exploit opportunities ahead of competitors, indicating a higher level of DC use (Zahra et al., 2006). The development of DC is directly related to the entrepreneurial, management and leadership skills to draw, develop, implement and modify processes to adapt to the market (Constance E. Helfat et al., 2007). These statements are in accordance with Schumpeter's (1934) definition of the entrepreneur as someone who takes risks in search of innovation and new combinations of resources to satisfy the consumers' needs.
Considering AC, doubt still remains as to how SMEs have the capacity to absorb external knowledge, as they have limited financial resources, simpler structure, more simplified organizational routines, and little access to the scientific community compared to large companies. According to Wang et al., (2010) the AC of these companies resides not only in financial investments but also in the experience of their owners and their team of R\&D . In these companies, it is usually the managers' behavior, personal characteristics, skills, beliefs, and method of work that strengthen AC (Talebi \& Tajeddin, 2011; Wang et al., 2010), mainly in respect to Potential AC (Branzei \& Vertinsky, 2006). Other aspects that are seen as influencers of an SME's AC are R\&D investments (Talebi \& Tajeddin, 2011), systems thinking and alliances for exchanging knowledge with other companies (Tranekjer \& Knudsen, 2012) as well as the constant adoption of new processes and development strategies (Branzei \& Vertinsky, 2006).

Branzei \& Vertinsky (2006) state that AC in SMEs is relevant to reshape the stagnant capabilities of the company and enable better adaptation of external changes in organizational strategies (Branzei \& Vertinsky, 2006). According to these authors, the Potential AC in SMEs is influenced by the capacity of human resources and the constant search to renew organizational routines. Additionally, SMEs seeking market growth develop Potential AC more easily, since they periodically redesign layout, train employees and update their routines and technology. Realized AC is positively influenced by the development strategies of human resources in the organization but is negatively influenced by changes in routine processes, that is, when the SME puts less emphasis on process, changes achieve greater Realized AC. Similarly, Realized AC is enhanced by new product development strategies.

Large companies have abundant resources to create new knowledge; thus, external knowledge exploitation is not so important as it is for small firms (Wang et al., 2010). On the other hand, the lack of resources in small businesses makes them more dependent on external sources to develop new knowledge and products (Wang et al., 2010), which demonstrates the relevance of $\mathrm{AC}$ in the innovative performance of these companies.

A holistic view of AC depicts the concept of DC, which cannot be separated from systems, processes and organizational structures (Sun \& Anderson, 2010). Thus, the present study compares SMEs and large companies in respect to the influence of DC in innovative performance. For this, we adopted the framework of $\mathrm{AC}$ and its dimensions, Potential AC and Realized AC (Zahra \& George, 2002) and previous studies that support the relationship of AC to innovation performance (Moilanen et al., 2014; Wang et al., 2010). The research hypothesis that this study seeks to verify is thus the following:

H1: Organizational size moderates the relationship between absorptive capacity dimensions and innovation performance. 


\section{Method}

\subsection{Data}

To evaluate the research framework based on Zahra \& George (2002) and the research hypothesis (H1), we use cross-sectional data from PINTEC 2008 (Brazilian Innovation Survey), a biannual-triannual innovation survey conducted since 2000 in Brazil. For the 2008 survey, data were collected on the innovation activities of companies during the 3-year period from 2006 to 2008 . The methodological approach adopted by PINTEC follows the one utilized by CIS (Community Innovation Survey) in Europe; both are structured by the guidelines of the Oslo Manual. Since it covers all countries and provides a firm data level, the PINTEC is a relevant source of information for the research question posed by this study.

Because this survey has been conducted for more than 10 years, there are scattered studies that place the data in a theoretical framework going beyond the data itself. For example, while Derbyshire (2014) analyzed the relationship between ambidexterity and firm performance in Europe using CIS dataset, most of the studies in Brazil examine only the characteristics of the firms (Kannebley, Porto, \& Pazello, 2005). Furthermore, there is a gap in prior studies concerning the use of up-to-date editions of PINTEC (2008 and 2011). Santos, Basso, Kimura, \& Kayo (2014) have published one of most recent studies using PINTEC data, which analyze the relationship between innovative investments and financial performance, but the study draws from PINTEC 2000, 2003 and 2005.

Considering the gaps above, this research adds to the literature in two ways. First, it addresses the lack of studies that have drawn from the most recent versions of PINTEC. If one compares the two most recent editions available, 2008 and 2011, the 2008 edition was chosen because the final sample for the selected sector was larger. That is relevant because of the statistical technique used: structural equation modeling (SEM) demands a larger sample, and this need is intensified by the fact that the PINTEC has an ordinal scale ranging from 1 to 4 (more details in Section 3.3). Second, we place representative firm data collected in a national survey in a consistent theoretical framework. That is, this study uses the PINTEC dataset to evaluate the differences between SMEs and large companies in respect to the impact of Potential and Realized AC on innovation performance.

The changing nature of a competitive environment stimulates the necessity of AC development, but in the information and communication technology (ICT) industry, this need becomes even more evident once this sector is characterized as high-growth and knowledge-intensive in the midst of global competition (Saarenketo, Puumalainen, Kyläheiko, \& Kuivalainen, 2008). Therefore, this study is restricted to this sector, and this type of sectorial boundary delimits a sample of companies facing comparative knowledge flows and competition levels.

Thus, due to our methodological choices and the design of the PINTEC questionnaire, the companies comprising the final sample (1) are established in Brazil, even the foreign-controlled ones, (2) have implemented some innovation between 2006 and 2008 (3) and operate in the information and communication technology sector (ICT), and they are all identified through the National Classification of Economic Activities (CNAE) accordingly to the IBGE's categorization for the sector (Instituto Brasileiro de Geografia e Estatística, 2009). These boundaries have resulted in 1443 companies in the final sample.

\subsection{Measures}

\subsubsection{Organizational size}

According to the IBGE criteria, the sample was split into two parts, considered SMEs: the manufacturers with 500 or fewer employees and services firms with 100 or fewer. This measure takes into account the differences related to labor intensity among manufacturers and service firms. Therefore, the sample comprises 1118 SMEs and 325 large firms.

One may argue that as organizations grow, they incrementally change, which would lead to choosing a continuous rather than dichotomous measure of organizational size. However, in Brazil, companies have tax incentives, preferences in public bids, free technical and managerial training, and other distinctive conditions that shape organizational behavior based on strict ranges of size. Moreover, the strategy of splitting the sample into groups clearly addresses the research objective of comparing SMEs to large companies.

\subsubsection{Potential and Realized AC}

Consonant with the DC vision, the choice of the indicators for each construct of the model followed an evolutionary approach (Nelson \& Winter, 1982). Instead of using a single measure of AC (e.g., R\&D intensity), which is contrary to the usual convention of studies with national innovation, this study measures each dimension of AC (Potential AC and Realized AC) individually with multiple indicators.

Considering the critiques of Andersén \& Kask (2012), an evolutionary approach to $\mathrm{AC}$ cannot conceive itself along the dimensions of Potential AC and Realized AC exactly in the way stated by Zahra \& George (2002). In this way, the measurements of Potential and Realized AC capacities are related to the effective use of the capacities, which is in contrast to static approaches based on the qualification for use (Andersén \& Kask, 2012).

Thus, Potential AC indicators represent an organizational disposition to capture external knowledge that is measured by the effective capacity of use of external sources of knowledge for innovation. As the Potential AC promotes the continuous renewal of the stock of knowledge, items were selected for transfer and assimilation This includes items related to the explicit flow of external information, which is considered the initial input of AC (W. M. Cohen \& Levinthal, 1990; Zahra \& George, 2002).

Realized AC indicators were selected concerning the modification of the resource base that provided evidence of internal changes in the organization. In other words, Realized AC indicators capture the 
firm's capacity for action, that is, the indicators convert the external knowledge into results (Andersén \& Kask, 2012; Zahra \& George, 2002). As was done in the Potential AC, all indicators necessarily follow from the R\&D activities. These measures represent an improvement over the usual measures, such as patents and intensity of R\&D, by (1) capturing a wider range of innovations and (2) reflecting efforts to change the competitive level of the organization.

\subsubsection{Innovation Performance}

Finally, innovation performance is measured through market impacts of a given firm's innovations during the given period (Ritala, 2012).
The indicators take account of the market effects of the innovation of products and processes in the period evaluated on the belief that these effects are the best representatives of innovation performance. This is because the external knowledge internalized through processes and routines acquires tangibility in technology, whereby a technique overcomes a given problem (Nelson \& Winter, 1982).

Table 1 details the indicators selected for the study. In terms of empirical support, there is research on AC in Brazil (Alves, 2015; Alves \& Galina, 2016) and in Europe with the CIS (Archibugi, Filippetti, \& Frenz, 2013; Escribano, Fosfuri, \& Tribó, 2009; Kostopoulos, Papalexandris, Papachroni, \& Ioannou, 2011) that supports this choice.

Table 1

Indicators of the constructs

$\underline{\text { Potential AC }}$

(Cronbach's $\alpha=0.7951)$

Importance attributed to each category of information source used for development of new or substantially improved products and/ or processes in the study period:

- PC1: Suppliers of machines, equipment, materials, components or software

- $\quad$ PC2: Clients and consumers

- PC3: Competitors

- PC4: Consulting companies and independent consultants

- PC5: Universities and other higher teaching centers

- PC6: Research institutes or technology centers

- $\quad$ PC7: Professional qualification and technical assistance centers

- $\quad$ PC8: Establishment of tests, trials and certifications

- PC9: Conferences, meetings and specialized publications

- PC10: Fairs and expositions

- PC11: Computer information networks (e.g. Internet, extranet, intranet, etc.)

\section{$\underline{\text { Realized AC }}$}

(Cronbach's $\alpha=0.7640$ )

Importance attributed to each category of information source used for development of new or substantially improved products and/or processes in the study period:

- RC1: Improved the quality of goods and services

- $\quad$ RC2: Extended the range of supplies

- RC3: Increased the capacity of production or services

- RC4: Increased the flexibility of production or services

- RC5: Reduced the production costs

- RC6: Reduced the labor costs

- RC7: Reduced the energy consumption
Innovation performance (Cronbach's $\alpha=0.7326$ )

Importance attributed to each category of external impact resulting from new or substantially improved products and/or processes in the study period:

- IP1: Allowed the company to maintain participation in the market

- IP2: Extended the company's participation in the market

- IP3: Allowed the company to open new markets

Note. Elaborated by the authors. 


\subsection{Analysis strategy}

The data analysis consisted of two steps to test the theoretical model (Stage 1) and two steps to test the hypothesis of the study (Stage 2). First, the model was evaluated through confirmatory factor analysis (CFA) and, second, through structural equation modeling (SEM). Given the categorical scale adopted by PINTEC (4-point scale concordance), estimation was performed by using the asymptotic distribution-free method (Jöreskog \& Sörbom, 1996). These two steps allowed a robust test of the theoretical framework (Hoyle, 2012) with a single sample (Stage 1).

After validating the model, the third step involved testing the difference between when the model adjustment was unconstrained and when the model adjustment was constrained for the parameters to be equal between the two groups (SMEs and large companies). Next, the fourth step tested the differences between the models' coefficients. To compare the model adjustment, the chi-square test was used (Hoyle, 2012), and to compare the coefficients of the models, the z-test procedure was used (Paternoster, Brame, Mazerolle, \& Piquero, 1998). This

Table 2

Results of convergent validity and internal consistency reliability

\begin{tabular}{|c|c|c|c|c|c|}
\hline Construct & Indicators & Mean & Loading & $\mathrm{CR}$ & AVE \\
\hline \multirow[t]{11}{*}{ Potential AC } & PC1 & 2.674 & * & 0.747 & 0.426 \\
\hline & PC2 & 3.261 & * & & \\
\hline & PC3 & 2.432 & * & & \\
\hline & PC4 & 2.053 & * & & \\
\hline & PC5 & 1.831 & 0.630 & & \\
\hline & PC6 & 1.738 & 0.715 & & \\
\hline & PC7 & 1.723 & 0.662 & & \\
\hline & PC8 & 1.968 & 0.598 & & \\
\hline & PC9 & 2.493 & * & & \\
\hline & PC10 & 2.599 & * & & \\
\hline & PC11 & 3.385 & * & & \\
\hline \multirow[t]{6}{*}{ Realized AC } & $\mathrm{RC} 1$ & 3.354 & 0.715 & 0.762 & 0.447 \\
\hline & $\mathrm{RC} 2$ & 3.087 & 0.727 & & \\
\hline & $\mathrm{RC} 3$ & 2.888 & 0.602 & & \\
\hline & $\mathrm{RC} 4$ & 2.835 & 0.621 & & \\
\hline & RC5 & 2.199 & * & & \\
\hline & RC6 & 1.427 & * & & \\
\hline \multirow[t]{3}{*}{ Innovation Performance } & IP1 & 3.270 & 0.848 & 0.851 & 0.656 \\
\hline & IP2 & 2.993 & 0.814 & & \\
\hline & IP3 & 2.845 & 0.767 & & \\
\hline
\end{tabular}

Note. Elaborated by the authors.

* Indicators removed in the final model due low loadings.

Table 3

Results of discriminant validity

\begin{tabular}{|c|c|}
\hline Relationships & HTMT \\
\hline Potential AC and Realized AC & 0.346 \\
\hline Realized AC and Innovation Performance & 0.437 \\
\hline Potential AC and Innovation Performance & 0.856 \\
\hline
\end{tabular}

two-level analysis strategy strengthens the results because they were evaluated to yield the difference between the models overall as well as the degree to which the relations are different (Stage 2).

\section{Results}

\subsection{Stage 1}

Following technical procedures and cutoffs suggested by Hoyle (2012), the CFA results shows that the final model presents good quality measures because it achieved validity in terms of convergent, discriminant, and nomological, besides internal consistency (Table 2). The mean variance extracted should be higher than 0.50 to obtain a convergent validity (Nunnally, 2010). The constructs of Potential AC and Realized AC have slightly lower values, but small values do not have any negative effect if the composite reliability is higher than 0.70 (Fornell \& Larcker, 1981). Therefore, because the lowest composite reliability value is 0.747 , the validity of the model is ensured. Moreover, the heterotrait-monotrait ratio (HTMT) of correlations with the conservative cut-off of 0.85 (Henseler, Ringle \& Sarstedt, 2015) assures the discriminant validity of the model (Table 3 ).

Note. Elaborated by the authors. 
In light of the results of CFA, Table 4 provides the results of the structural model. The fit statistics of the model were found to be satisfactory, although the model had been penalized by some of these statistics due to the sample size. For example, chi-square statistics tend to be significant for samples greater than 200 .

Table 4

Structural model fit indices

\begin{tabular}{lll}
\hline Fit Indices & Model Results & Reference Values \\
$\chi^{2}$ & 139.647 & \\
$\mathrm{p}>\chi^{2}$ & 0.000 & $\mathrm{p}>0.05$ (Nunnally, 2010) \\
$\chi^{2} / \mathrm{df}$ & 3.675 & $<5.00$ (Wheaton, Muthen, Alwin, \& Summers, 1977) \\
RMSEA & 0.043 & $<0.10$ (MacCallum, Browne, \& Sugawara, 1996) \\
RMSEA (p-close) & 0.928 & $\mathrm{p}>0.05$ (Nunnally, 2010) \\
CFI & 0.948 & $>0.85$ (Marsh, Hau, \& Wen, 2004) \\
TLI & 0.925 & $>0.85$ (Marsh et al., 2004) \\
SRMR & 0.040 & $<0.10$ (Marsh et al., 2004) \\
CD & 0.985 & $>0.26$ (J. Cohen, 2009) \\
\hline
\end{tabular}

Note. Elaborated by the authors.

These results comprised the first two steps of the analysis, the sample not being split (Stage 1). Due to the limited space and the fact that these results are not central to the discussion regarding H1, they are not discussed in detail here.

\subsection{Stage 2}

Table 5 and Table 6 present the main results. The first one supports H1: SMEs differ from large companies in terms of the relationship between absorptive capacity and innovation performance $(\mathrm{p}<0.01)$. Chi-square difference in Table 5 shows that the model is significantly different, which means that when the parameters of the model are forced to be equal between the two groups, the statistic adjustment is degraded (139.65 vs. 332.43). Since the AC model is different, it is worth noting the way in which they are different.

Table 5

Test of invariance

\begin{tabular}{llll}
\hline Model & $\chi^{2}$ & $d f$ & $\Delta \chi^{2}(d f)$ \\
Unconstrained & 139.65 & 38 & - \\
Constrained & 332.43 & 115 & $192.78(77)^{* * *}$ \\
\hline
\end{tabular}

Note. Elaborated by the authors.

${ }^{*}$ p-value $<0.10,{ }^{* *}$ p-value $<0.05,{ }^{* * *}$ p-value $<0.01$ level.

Table 6 shows two main findings. First, the two first structural paths (Potential AC $\rightarrow$ Realized AC and Realized AC $\rightarrow$ IP) are statistically significant for both groups $(\mathrm{p}<0.01)$, but they differ in respect to the effect of Realized AC on innovation performance $(\mathrm{p}<0.01)$. It means that for SMEs, the effect of Realized AC in innovation performance is $18 \%$ higher ( 0.8933 vs. 0.7547$)$.
Second, while SMEs follow a model without indirect effects from Potential AC to innovation performance, large companies present a model with a relationship between these constructs. The difference between the two groups is statistically significant $(\mathrm{p}<0.05)$, that is, Potential AC impacts innovation performance in large companies, but it does not in SMEs.

Table 6

Structural coefficients comparison

\begin{tabular}{llll}
\hline Structural Path & SMEs & Large companies & Z-test \\
Potential AC $\rightarrow$ Realized AC & $0.2206^{* * *}$ & $0.1840^{* * *}$ & 0.4790 \\
Realized AC $\rightarrow$ Innovation Performance & $0.8933^{* * *}$ & $0.7547^{* * *}$ & $2.7978^{* * *}$ \\
Potential AC $\rightarrow$ Innovation Performance & 0.0013 & $0.0961^{*}$ & $-1.6702^{* *}$ \\
\hline
\end{tabular}

Note. Elaborated by the authors.

${ }^{\star}$ p-value $<0.10,{ }^{* *}$ p-value $<0.05,{ }^{* * *}$ p-value $<0.01$ level. 
Finally, the R-squared of Innovation Performance construct is $79.8 \%$ for SMEs and $60.5 \%$ for large companies. This result indicates that not only the model behavior is different between the groups (as presented before), but also the percentage explained of the variation of Innovation Performance is more than $30 \%$ higher in SMEs.

\section{Discussion and final remarks}

This study examines how the firm's size affects the behavior of DC, more precisely, it analyzes the AC. The hypothesis was tested empirically, and we found strong statistical support for our position: AC impacts $30 \%$ more innovative performance of SMEs than of large companies. The analyses indicated that both SMEs and large companies build their Realized AC from Potential AC. However, only large companies can improve innovation performance directly from Potential AC. The study also confirms that SMEs are more efficient in converting Realized AC in innovation performance.

These findings add to the existing literature in different forms. First, it shows that capability building to learn from external sources relies on individual and group level (Potential AC) to achieve organizational levels (Realized AC) no matter the size of the company, as disclosed by Sun \& Anderson (2010). That is, SMEs and large companies need to develop intuition and interpretation processes to obtain variation, in evolutionary terms. Traditional barriers such as rigid structures and systems do not seem to matter in regard to developing organizational level capabilities, such as Realized AC.

Second, this study shows that large companies capitalize on Potential AC for innovation, which does not happen within SMEs. This can be understood as a strategic rather than operational use of AC in respect to Realized AC. Large companies have greater access to market and financial resources where external knowledge can drive strategic changes and improve performance. Beyond that, large companies create around themselves a complex network of other companies that allow them to outsource the process to transform and explore external knowledge; thereby they reduce risk. This last explanation is consistent with the existing literature: large companies are less willing to take risks.

Third, (this is in some ways complementary to the last point) the analysis of organizational size in this study shows that SMEs convert Realized AC into innovation performance better than large companies. This suggests that flexibility and agility play a more relevant role than access to resources. For evolutionary economics, Realized AC is concerned with a selection process that drives changes. As companies become larger, they reduce their capacity to change and adjust to environmental circumstances, and, more importantly, their path dependence makes them more likely to experiment competence traps. Furthermore, the different business units and the complex networks that involve large firms make it difficult to apply external knowledge and improve performance. In another way, SMEs have more easily reduced costs of coordination and deals through tacit knowledge. Because Realized AC relies on the organizational level but is driven by experimentation and leadership, size is important to converting it into performance.
Fourth, this study contributes to open the black box of DC. In a broader view, this study connects a traditional stream of research related to organizational size with the DC view. This adds to the existing literature because it shows that even with reduced resources and evolutionary routines not established, SMEs develop DC. However, this happens differently from large companies. More specifically, this study shows that the model, which conceived AC as DC, is surprisingly more adhesive to SMEs than to large companies. While in SMEs, Realized AC fully mediates the relationship between Potential AC and innovation performance, as predicted by Zahra \& George (2002), large companies also present an effect not mediated.

In sum, the results contribute to show that in high-velocity markets, as is the case of companies in the study sample (ICT sector), may be positive for the development of DC to be a SMEs, which are usually characterized as having limited financial resources, simpler structure, more simplified organizational routines, and little access to the scientific community when compared to large companies.

In addition, probably the most important theoretical implication is to contribute a response to following question: "under what conditions does the presence of DC in firms generate competitive advantage?” (Verona \& Zollo, 2011, p. 537). Instead of providing an answer establishing boundaries or optimum levels, the results suggest that the presence of DC assumes different configurations depending on the organizational size. Thus, DC indeed do generate performance in SMEs and large companies, but they do so in distinct ways.

In terms of managerial implications, this study suggests that building up DC is an investment with returns for both SMEs and large companies. However, the way the capabilities deploy the resources to impact performance demands managerial attention. The structure of a firm needs to be taken into account while managing DC. The recognition of how routines can assume many forms and even become rule-based due to the organizational size may allow managers to realize the potential of DC. Concerning specifically AC, the results indicate that the benefits of this dynamic capability related with external knowledge are higher for SMEs. Consequently, these companies can expect more returns engaging in these routines.

As expected, given the exploratory nature of the research concerning organizational size and DC, this study has limitations that may drive future studies. The two most important are that it deployed only cross-sectional data and that the size was operationalized along two groups. To address the first limitation, it would help to understand the temporal dynamic of capability building. To address the second limitation, it would help to allow for the exploration of the effect of size on DC in terms of the curve's shape resembling a linear or inverted $U$.

\section{References}

Adner, R., \& Helfat, C. E. (2003). Corporate effects and dynamic managerial capabilities. Strategic Management Journal, 24(10), 1011-1025. http://doi.org/10.1002/smj.331 
Alves, A. C., Zen, A. C., \& Padula, A. D. (2011). Routines, Capabilities and Innovation in the Brazilian Wine Industry. Journal of Technology Management \& Innovation, 6(2), 128-144. http://doi.org/10.4067/ S0718-27242011000200009

Alves, M. F. R. (2015). Absorptive capacity: theoretical bases, operation and conditionings (Masters dissertation). University of Sao Paulo, Ribeirão Preto. Retrieved from https://doi.org/10.11606/D.96.2015. tde-02092015-101039

Alves, M. F. R., \& Galina, S. V. R. (2016). Innovative performance and the configuration of potential and realized absorptive capacities. Presented at the Sixth Annual Conference of Academy of International Business - Latin American Chapter (AIB-LAT), Sao Paulo.

Andersén, J., \& Kask, J. (2012). Asymmetrically realized absorptive capacity and relationship durability. Management Decision, 50(1), 43-57. http://doi.org/10.1108/00251741211194868

Archibugi, D., Filippetti, A., \& Frenz, M. (2013). Economic crisis and innovation: Is destruction prevailing over accumulation? Research Policy, 42(2), 303-314. http://doi.org/10.1016/j.respol.2012.07.002

Arend, R. J. (2014). Entrepreneurship and dynamic capabilities: how firm age and size affect the "capability enhancement-SME performance" relationship. Small Business Economics, 42(1), 33-57. http:// doi.org/10.1007/s11187-012-9461-9

Ben-Menahem, S. M., Kwee, Z., Volberda, H. W., \& Van Den Bosch, F. A. J. (2013). Strategic Renewal Over Time: The Enabling Role of Potential Absorptive Capacity in Aligning Internal and External Rates of Change. Long Range Planning, 46(3), 216-235. http://doi. org/10.1016/j.lrp.2012.09.012

Branzei, O., \& Vertinsky, I. (2006). Strategic pathways to product innovation capabilities in SMEs. Journal of Business Venturing, 21(1), 75-105. http://doi.org/10.1016/j.jbusvent.2004.10.002

Cantú, L. Z., Criado, J. R., \& Criado, A. R. (2009). Generation and transfer of knowledge in IT-related SMEs. Journal of Knowledge Management, 13(5), 243-256. http://doi.org/10.1108/13673270910988088

Cohen, J. (2009). Statistical power analysis for the behavioral sciences (2. ed., reprint). New York, NY: Psychology Press.

Cohen, W. M., \& Levinthal, D. A. (1990). Absorptive Capacity: A New Perspective on Learning and Innovation. Administrative Science Quarterly, 35(1), 128. http://doi.org/10.2307/2393553

Curran, J., \& Blackburn, R. A. (2001). Researching the small enterprise. London ; Thousand Oaks, Calif: SAGE Publications.

Derbyshire, J. (2014). The impact of ambidexterity on enterprise performance: Evidence from 15 countries and 14 sectors. Technovation, 34(10), 574-581. http://doi.org/10.1016/j.technovation.2014.05.010
Eisenhardt, K. M., \& Martin, J. A. (2000). Dynamic capabilities: what are they? Strategic Management Journal, 21(10-11), 1105-1121. http://doi.org/10.1002/1097-0266(200010/11)21:10/11<1105::AIDSMJ133>3.0.CO;2-E

Escribano, A., Fosfuri, A., \& Tribó, J. A. (2009). Managing external knowledge flows: The moderating role of absorptive capacity. Research Policy, 38(1), 96-105. http://doi.org/10.1016/j.respol.2008.10.022

Frank, H., \& Roessl, D. (2015). Problematization and conceptualization of "entrepreneurial SME Management" as a field of research: overcoming the size-based approach. Review of Managerial Science, 9(2), 225-240. http://doi.org/10.1007/s11846-014-0154-4

Helfat, C. E., Finkelstein, S., Mitchell, W., Peteraf, M., Singh, H., Teece, D., \& Winter, S. G. (2007). Dynamic Capabilities: Understanding Strategic Change in Organizations. Wiley.

Helfat, C. E., \& Martin, J. A. (2015). Dynamic Managerial Capabilities: Review and Assessment of Managerial Impact on Strategic Change. Journal of Management, 41(5), 1281-1312. http://doi. org/10.1177/0149206314561301

Helfat, C. E., \& Winter, S. G. (2011). Untangling Dynamic and Operational Capabilities: Strategy for the (N)ever-Changing World. Strategic Management Journal, 32(11), 1243-1250. http://doi.org/10.1002/smj.955

Hoyle, R. H. (Ed.). (2012). Handbook of structural equation modeling. New York: Guilford Press.

Instituto Brasileiro de Geografia e Estatística. (2009). O setor de tecnologia da informação e comunicação no Brasil, 2003-2006. Rio de Janeiro: IBGE.

Jöreskog, K. G., \& Sörbom, D. (1996). LISREL 8: User's Reference Guide. Scientific Software International.

Kannebley, S., Porto, G. S., \& Pazello, E. T. (2005). Characteristics of Brazilian innovative firms: An empirical analysis based on PINTEC-industrial research on technological innovation. Research Policy, 34(6), 872-893. http://doi.org/10.1016/j.respol.2005.04.003

Kostopoulos, K., Papalexandris, A., Papachroni, M., \& Ioannou, G. (2011). Absorptive capacity, innovation, and financial performance. Journal of Business Research, 64(12), 1335-1343. http://doi. org/10.1016/j.jbusres.2010.12.005

MacCallum, R. C., Browne, M. W., \& Sugawara, H. M. (1996). Power analysis and determination of sample size for covariance structure modeling. Psychological Methods, 1(2), 130-149. http://doi. org/10.1037/1082-989X.1.2.130

Marsh, H. W., Hau, K.-T., \& Wen, Z. (2004). In Search of Golden Rules: Comment on Hypothesis-Testing Approaches to Setting Cutoff Values for Fit Indexes and Dangers in Overgeneralizing Hu and Bentler's (1999) Findings. Structural Equation Modeling: A Multidisciplinary Journal, 11(3), 320-341. http://doi.org/10.1207/s15328007sem1103_2 
Moilanen, M., Østbye, S., \& Woll, K. (2014). Non-R\&amp;D SMEs: external knowledge, absorptive capacity and product innovation. Small Business Economics, 43(2), 447-462. http://doi.org/10.1007/ s11187-014-9545-9

Nelson, R. R., \& Winter, S. G. (1982). An Evolutionary Theory of Economic Change. Harvard University Press.

Nunnally. (2010). Psychometric Theory 3E. McGraw-Hill Education (India) Pvt Limited.

Paternoster, R., Brame, R., Mazerolle, P., \& Piquero, A. (1998). USING THE CORRECT STATISTICAL TEST FOR THE EQUALITY OF REGRESSION COEFFICIENTS. Criminology, 36(4), 859-866. http://doi.org/10.1111/j.1745-9125.1998.tb01268.x

Rindova, V. P., \& Kotha, S. (2001). CONTINUOUS "MORPHING": COMPETING THROUGH DYNAMIC CAPABILITIES, FORM, AND FUNCTION. Academy of Management Journal, 44(6), 12631280. http://doi.org/10.2307/3069400

Ritala, P. (2012). Coopetition Strategy - When is it Successful? Empirical Evidence on Innovation and Market Performance. British Journal of Management, 23(3), 307-324. http://doi.org/10.1111/j.14678551.2011.00741.x

Saarenketo, S., Puumalainen, K., Kyläheiko, K., \& Kuivalainen, O. (2008). Linking knowledge and internationalization in small and medium-sized enterprises in the ICT sector. Technovation, 28(9), 591-601. http://doi.org/10.1016/j.technovation.2007.12.003

Santos, D. F. L., Basso, L. F. C., Kimura, H., \& Kayo, E. K. (2014). Innovation efforts and performances of Brazilian firms. Journal of Business Research, 67(4), 527-535. http://doi.org/10.1016/j.jbusres.2013.11.009

Schilke, O. (2014). On the contingent value of dynamic capabilities for competitive advantage: The nonlinear moderating effect of environmental dynamism. Strategic Management Journal, 35(2), 179-203. http://doi.org/10.1002/smj.2099

Schumpeter, J. A. (1934). The Theory of Economic Development: an Inquiry into Profits, Capital, Credit, Interest, and the Business Cycle.

Sun, P. Y. T., \& Anderson, M. H. (2010). An Examination of the Relationship Between Absorptive Capacity and Organizational Learning, and a Proposed Integration: Absorptive Capacity and Organizational Learning. International Journal of Management Reviews, 12(2), 130150. http://doi.org/10.1111/j.1468-2370.2008.00256.x

Talebi, K., \& Tajeddin, M. (2011). The adoption of new and innovative knowledge by small and medium enterprises of Iran: Opportunities and constraints for growth. African Journal of Business Management, 5(1), 39-49. http://doi.org/10.5897/AJBM10.366
Teece, D. J. (2007). Explicating dynamic capabilities: the nature and microfoundations of (sustainable) enterprise performance. Strategic Management Journal, 28(13), 1319-1350. http://doi.org/10.1002/ smj.640

Teece, D. J. (2016). Dynamic capabilities and entrepreneurial management in large organizations: Toward a theory of the (entrepreneurial) firm. European Economic Review, 86, 202-216. http://doi. org/10.1016/j.euroecorev.2015.11.006

Teece, D. J., Pisano, G., \& Shuen, A. (1997). Dynamic capabilities and strategic management. Strategic Management Journal, 18(7), 509-533. http://doi.org/10.1002/(SICI)1097-0266(199708)18:7<509::AIDSMJ882>3.0.CO;2-Z

Tranekjer, T. L., \& Knudsen, M. P. (2012). The (Unknown) Providers to Other Firms' New Product Development: What's in It for Them?: What's in It for Unknown Providers? Journal of Product Innovation Management, 29(6), 986-999. http://doi.org/10.1111/j.15405885.2012.00974.x

Verona, G., \& Zollo, M. (2011). The Human Side of Dynamic Capabilities: A Holistic Learning Model. In M. Easterby-Smith \& M. A. Lyles (Eds.), Handbook of Organizational Learning and Knowledge Management (pp. 535-550). Hoboken, NJ, USA: John Wiley \& Sons, Inc. Retrieved from http://doi.wiley.com/10.1002/9781119207245.ch24

Wang, C. L., \& Ahmed, P. K. (2007). Dynamic capabilities: A review and research agenda. International Journal of Management Reviews, 9(1), 31-51. http://doi.org/10.1111/j.1468-2370.2007.00201.x

Wang, Y., Wang, Y., \& Horng, R. (2010). Learning and innovation in small and medium enterprises. Industrial Management \& Data Systems, 110(2), 175-192. http://doi.org/10.1108/02635571011020296

Wheaton, B., Muthen, B., Alwin, D. F., \& Summers, G. F. (1977). Assessing Reliability and Stability in Panel Models. Sociological Methodology, 8, 84. http://doi.org/10.2307/270754

Zahra, S. A., \& George, G. (2002). Absorptive Capacity: A Review, Reconceptualization, and Extension. Academy of Management Review, 27(2), 185-203. http://doi.org/10.5465/AMR.2002.6587995

Zahra, S. A., Sapienza, H. J., \& Davidsson, P. (2006). Entrepreneurship and Dynamic Capabilities: A Review, Model and Research Agenda*. Journal of Management Studies, 43(4), 917-955. http://doi. org/10.1111/j.1467-6486.2006.00616.x

Zollo, M., \& Winter, S. G. (2002). Deliberate Learning and the Evolution of Dynamic Capabilities. Organization Science, 13(3), 339-351. http://doi.org/10.1287/orsc.13.3.339.2780 